\title{
TRANSMISSION OF TRADITION THROUGH SONG, RECITATION AND PRAYER IN LEMBA COMMUNITIES
}

The Lemba live among other peoples in southern Africa, speak the language of the populations surrounding them, attend local schools and hold positions in their communities, mainly in the southern parts of Zimbabwe, the Soutpansberg area and Sekhukhuneland. But their uniqueness lies in the fact that they regard themselves as 'children of Abraham', who centuries ago left their city called Sena, crossed the 'Phusela' and came to Africa as traders. Memories are kept alive by oral traditions incorporated in most of their songs, recitations and prayers. The possibility that the Lemba may have a Semitic ancestry (embedded in an African culture) is further suggested by their enthusiasm for religious practices like circumcision rites, ritual slaugther, food taboos, New Moon Festivals and many more.

During a field study, conducted 1995 and 1997, I made use of qualitative reseach methods that included participant observation and in-depth interviewing. I interviewed many Lemba people and collected as many oral traditions as possible. In this project, oral traditions which were obtained from the Lemba by means of recorded performances, interviews, etc., were translated directly by an interpreter from the original language into English, while they were being taped. Thereafter they were transcribed and documented. As far as possible the actual words of the participants were retained in the transcription. I was surprised to learn that despite their traditions of origin the majority of the Lemba whom I interviewed had embraced Christianity.

Already in 1908 Junod concluded that the advent of the European civilisation was rather disastrous to the Balemba, because European wares and wire were surplanting theirs, and Christianity caused them to lose their special characteristics.' I am mainly concerned with the role of the songs (and musical instruments), recitations and prayers in the Lemba communities through which their traditions are transmitted (these being the core of their historical and religious consciousness), the possible meaning behind those songs, poems and prayers, the possible religious thinking they reflect

1 H.A. Junod, The Balemba of the Zoutpansberg (Transvaal), Folk-Lore 19 (1908) 276-287.

Koninklijke Brill NV, Leiden, 2000

Exchange 29,4 
and to invesitigate to what extent Christianity found expression in them. But before attending to these songs, recitations and prayers, I shall first give a brief summary of the Lemba's historical background available in oral traditions and written sources and then attend to the concept of oral traditions.

\section{Historical Background}

Nothing precise is known of the history of the Lemba north of the Zambesi, or even of the Lemba in the former Rhodesia (Zimbabwe) and we therefore have to rely heavily on oral traditions. Oral traditions do not provide us with chronology and for the purpose of historiography it is, therefore, very difficult to discern between the history of the Varemba in Zimbabwe and of those in the Soutpansberg and other areas. Because they were traders who moved around a great deal, it makes it even more difficult to determine where and when they lived.

In the 1860 s Wangemann collected several oral traditions on the origin of the Lemba and observed their most important customs. He reported that the Lemba "say, that earlier they lived at the River Loathe, with the Portuguese, they call themselves the Banyai-Bachalaka .. their fathers were great kings and wore masila (fabricated clothes) .. Earlier they lived next to Moselekazzi at the Zambezi." ${ }^{3}$

This tradition is in close relation to what some old Lemba of both the Spelonken and the Modjadji country later told:

[We] have come from a very remote place, on the other side of the Phusela [but they do not know where Phusela was]. We were on a big boat. A terrible storm nearly destroyed us all. The boat was broken into two pieces. One half of us reached the shores of this country; the others were taken away with the second half of the boat, and we do not know where they are now. ${ }^{4}$ We climbed the mountains and arrived among the Banyai. There we settled, and after a time we moved southwards to the Transvaal; but we are not Banyai. ${ }^{5}$

With the assistance of the Lemba Phophi (in the Soutpansberg area), Van Warmelo recorded similarly that the Lemba came from a remote place on the other side of the sea, but the informant added 'that they had come to

2 As the Lemba in Zimbabwe are known.

3 D. Wangemann, Ein Reise-Jahr in Süd-Afrika: ausführliches Tagebuch über eine in den Jahren 1866 und 1867 ausgefuihrte Inspectionsreise durch die Missions-Stationen der Berliner Missions-Gesellschaft, Berlin: Verlag des Missionshauses, 1868.

4 This sounds legendary, since it is improbable that only half a boat would sink. Obviously, it depends on what the boat looked like.

5 Junod, 'The Balemba of the Zoutpansberg', 277. 
Africa as traders'. They were in search of gold and after each trading expedition they went back to their country by the sea. They could not remember the name of their country but they were 'masters of iron and copper-smelting'. In their country they made pots, grew and wove cotton, and were also masters of timber-work, because they had to build their own ships for their maritime undertakings. ${ }^{6}$

At different places in Africa they erected trading depots and left some of their people behind to take charge. They did, however, keep themselves separate from the native peoples because they felt themselves superior. Then, according to their tradition, something bad happened in their country of origin -a war broke out and they (the savi or traders) could not return. Because they did not bring wives along, they now had to take wives from the 'gentiles' (the local peoples)- the Rozwi, Karanga, Zezuru and Govera tribes. $^{7}$

Among most clans of original Lemba stock, the tradition is to be found in various forms and in various places, that they reached their present home from across the Limpopo, but in the remote past they crossed the 'Phusela', from a place called Sena.

The oldest oral traditions and written documents available (e. g. the Assyrian inscriptions, $700 \mathrm{BC}$ and the Periplous) refer to the pre-IslamicArabian (Sabaean or Yemenite), Phoenician and Hebrew activities in Southeast Africa. ${ }^{8}$ At a very early stage, continuing influences between the Semitic world and that of the southeastern parts of Africa had a reciprocal impact on one another. Later documents (684-900 AD, e. g. the Arab and Portuguese) also refer to some kind of 'Moorish' people along the east coast of Africa. But from those written sources it is clear that authors were uneasy, or unable, to differentiate between for example Jews and Semites, Arabs and Muslims, Arabs and Swahili.

The possibility exists that the first pre-Islamic immigrants from Yemen related with the Mohammedan refugees who came much later to the east coast of Africa (followers of Zaid and Suleiman from Yemen in 684 AD), or the other way round. Whereas the leader of the Emozaid-Arabs (the Ameer) had his residence at Sena. Sena ${ }^{9}$ seems to be the place where the intermarriages between the locals and the Arabs (or Judaic-Arabs) from Yemen could have taken place. This could be the birthplace of the first

6 N.J. Van Warmelo, Zur Sprache und Herkunft der Lemba, Hamburger Beitrage zur Afrikakunde 5(1966), 273-283; cf. L.T. Marole, Lusakha Iwa Vha-Lemba. Sibasa: Marole Book Depot, 1969:1.

7 Van Warmelo, ibid.

8 D. H. Müller, 'Yemen', Encyclopaedia Brittanica, 1888 (9th ed). James B. Pritchard (ed.) Ancient Near Eastern Texts, Princeton: University Press, 1969.

9 On the banks of the Zambezi. George MacCall Theal, Records of south-eastern Africa, Cape Town: Struik, [1898-1903] reprint 1964, Vol 7:255,267; Junod, 'The Balemba of the Zoutspanberg', 25. 
real Lemba as we know them today. ${ }^{10}$

It is clear that there is no consensus about the origins of the Lemba and no consensus will probably ever be reached. Various authors wrote within their own contexts of time and location, and for this reason it is difficult to align the arguments of all these authors. A clear link between the various oral traditions can also not be established. Some studies conclude that where the Lemba's origin is dissected into its ethnic, religious, liguistic and cultural elements, there seems to be, among others, Judaic and Muslim, and Jewish and Arab elements. "It is striking that a considerable number of scholars opt for both a Jewish as well as an Islamic source or influence.

What we can say, is that the Lemba themselves, as well as all authors who studied them seriously, are in agreement that the Lemba constitute $a$ separate or distinct group from the Bantu groups who are their hosts. The Lemba are distinguised from others especially by their traditions of origin, customs, traditional religious practices, features, skills and aloofness. ${ }^{12}$ And many scholars hold that the Lemba have many customs with a Semitic or an Old Testament resonance.

A further possible conclusion from the information above could be that most of the references constitute to the presence of people mainly in the Zambezi region possessing notably Semitic characteristics without being clearly Muslims. It seems reasonable to assume that although the 'Moorish' or 'Arab' people were not specifically referred to, their traditions and customs were reminiscent of those people whom we know today as Varemba ('people who refuse'); Mushavi ('trader'); Vhasoni (great word of Lemba women); Mwenye ('foreigner', 'Arab', 'white people' or 'people of the light'); ${ }^{13}$ Malepa; Vha-Sena ('people of Sena at the Zambezi'); Vha-

10 H.P. Connoway, Herkoms, geskiedenis en genealogie van die Lembasibbes in Venda, Suid-Afrikaanse Tydskrif Etnologie I (1978/2), 31-44. M.E.R. Mathivha, The Basena/Vamwenye/Balemba, Morester: The Author, 1992.

11 J.B.N.D. De Vaal, Die Lemba: Die Semiete onder die Bantu van suidelike Afrika. Bantoe 7(1958), 51-74; B. Hendrickx, The ancient origin of the Lemba (Mwenye). A critical overview of the existing theories. Joumal of Oriental and African Studies 3 (1991), 172-193; M.N. Mphelo, The Balemba of the Northern Transvaal, Native Teacher's Joumal 16 (1936), 35-44; T. Parfitt, Joumey to the vanished city. The search for a lost tribe of Israel, London: Hodder \& Stoughton, 1992; T. Price, The Arabs of the Zambezi, The Muslim World 44 (1954), 31-37; A. B. Spurdle \& T. Jenkins, The origins of the Lemba, 'Black Jews' of southern Africa: evidence from p12F2 and other y-chromosome markers, American Jourmal for Human Genetics, 59 (1996), 1126-1133. L.C. Thompson, The Ba-Lemba of Southern Rhodesia, Native Affairs Department Annual 19 (1942), 76-86.

12 L. Frobenius, Die Waremba. Träger einer Fossilen Kultur, Zeitschrift für Ethnologie 70 (1938), 159-175.

13 This is only one possible translation. In the Handbook of Nyasaland (1936) the Amwenye are referred to as descendants from the Arabs, found by the Portuguese at Sena. 
lungu ('Europeans', 'non-Negro's' or 'strangers') or simply the Lemba or Balemba. ${ }^{14}$

The oral traditions of the Lemba and the historical, archaeological, and genetic data ${ }^{15}$ constitute the possibility that the immigration of the Lemba to Africa could have taken place even before the Christian era, but more probably before the 6th century $\mathrm{AD}$. Later migrations could also have occured but it is equally difficult to detemine. If we take the Yemenite Jews seriously, that they left Israel exactly forty two years before the destruction of the Temple, it seems that their descendants who at some time or another fled to Africa could still have borne a type of religion that could have similarities with early Israel (before the exiles had taken place). Therefore, in more than one way there seems to have been a historical link between the Lemba and Yemen.

\section{Orality among the Lemba}

The notion of 'oral traditions' is very wide and it should be more clearly defined and explained, since various viewpoints and definitions on oral traditions and folklore exist, as well as the possible differences between them. Vansina for example defines oral traditions as 'verbal messages which are reported statements from the past beyond the present generation.' $\mathrm{He}$ specifies that the 'message must be oral statements spoken, sung, or called out on musical instruments only ....' and maintains that 'this distinguishes such sources not only from written messages, but also from all other sources except oral history.' However, oral traditions can also be seen as 'the handing down of folklore from one generation to the next by word of mouth'. Folklore can be defined as 'the beliefs, customs, stories and sayings of a community passed on from one generation to another'. Two distinct facets emerge from Vansina and Deist's views, respectively. Different from Vansina who defines oral traditions as the verbal messages themselves, Deist defines them as the process or handing down of folklore. $^{16}$

For the purpose of this article I prefer to define 'oral traditions' as that which includes all songs, recitations, prayers, sayings, praises, and any historical or cultural statements from the past, transmitted from one generation to another. The term oral tradition, therefore, applies to both the

14 F.N Ravele, Traditions on the origin of the Lemba, Bantoe 7(1958), 76-78; also Hendrickx, 'The ancient origin of the Lemba', 174; Connoway, 'Herkoms..', 31.

15 M.G. Thomas, T. Parfitt, D.A. Weiss, K. Skorecki, M. Le Roux, N. Bradman, \& D.B. Goldstein, ' $Y$ chromosomes travelling south: The Cohen Modal Haplotype and the origins of the Lemba, the 'Black Jews of southern Africa', forthcoming in American Journal for Human Genetics.

16 J. Vansina, Oral traditions as history, London: James Currey, 1985, 27; F. E. Deist, A concise dictionary of theological terms with an English-Afrikaans and an Afrikaans-English list, Pretoria: Sigma, 1984, 63 and 119. 
process as well as its products. Among the various kinds of historical sources, traditions occupy a significant place. ${ }^{17}$

Oral cultures simply rely much less (mostly not at all) on reading and writing than do modern cultures. Most Lemba traditions are transmitted by means of songs, sermons, prayers, praises, proverbs, conversations, recitations, symbols, rituals, stories, written documents and numerous other mediums. Songs, recitations, as well as certain prayers, could be described as poems or set speech, which form part of everyday language and which are memorised. Stories and proverbs tend to be transmitted in a less fixed form as spoken prose, whereas praise songs or poems are chanted in various kinds of recitative, employing a semi-musical framework. Performances often combine words, as well as dance, and thus traditions can actually be conveyed by means of these performances. One of the striking characteristics of orality, over against written literature, is its verbal variability.

Vansina emphasises that sung messages in particular ensure reliability of transmission, since the 'melody acts as a mnemonic device' ${ }^{18}$ It needs to be explained that the Lemba musical background is both religious and secular. Music is necessary for communication with God, circumcision and initiation rites, marriage and funeral rites, as well as for secular purposes of ordinary singing and dancing. Antiphonal singing is also prominent in the religious music and in Nabarro' ${ }^{19}$ opinion some of the music and words used have a clear relationship with early Jewish music.

The Lemba people use a specific musical instrument which is, according to Nabarro, not found among other groups in South Africa. However, this instrument (and its variations) occurs in different forms in East Africa, Central Africa and Yemen and is called deza. Research by Nabarro have shown that other musical instruments used are those of the flute family, the kudu horn, drums for dancing, religious funeral rites as well as for the domba (initiation rites). Some of these instruments will be referred to below.

17 S. Niditch, Folklore and the Hebrew Bible, Minneapolis: Fortress, 1993:3; Idem, Oral world and written word. Ancient Israelite literature, Kentucky: Westminister John Knox, 1996:18.

18 Vansina, Oral Traditions as History, 16,46.

19 Hereby I acknowledge Dr Nabarro's dedicated research, specifically done on the music of the Lemba and how this corresponds to that of ancient Israel. Although we often met at the Lemba Conferences at Sweet Waters and briefly exchanged notes on our specific interests in the Lemba, I did not realise that we actually came to the same conclusion on the Lemba, namely that some of their prominent customs are closely related to that of pre-Talmudic Judaism. She undertook important research, which needs to be investigated further. Her untimely death in 1997 is a great loss for research on the Lemba. The personal notes and recordings of the late Dr Nabarro were placed at my disposal at a very late stage of my research among the Lemba. 
Lemba songs, chants, recitations and prayers are divided mainly into two groups: (i) Those which all (even uncircumcised non-Lemba) may hear; and (ii) those which are kept secret (only known by people circumcised by the Lemba). The latter are usually sung, chanted or prayed at special occasions, such as at the ritual slaughter of animals, or during the circumcision rites. ${ }^{20}$

The transmission of traditions also takes place during festivities and other 'formal' events of the Lemba (of which many are traditional African feasts and rituals) when the Lemba's own cultural traditions are recalled. In this way these are transmitted from one generation to another.

The occasions for public performances as expressions of traditions are limited and can generally only be observed in the field. In many parts of Africa, as well as among the Lemba, these tales are usually not to be told during daytime. ${ }^{21}$ No definite reasons are given for this, but the ideal setting is in the evenings, with the family sitting around the fire. Every performance is new, but presupposes something old, the tradition itself. To a certain extent, this is the same with our sermons today, the performance is new, but it presupposes something old.

Apart from the routine occasions during which the Lemba convey oral traditions to the younger generation, the LCA (Lemba Cultural Association) annually initiates the holding of a special conference at Sweet Waters, Elim, in the Northern Province and also at other places on special occasions. ${ }^{22}$ During these (LCA) occasions every possible means of communication is used to confirm their identity and to transmit this to the next generation. At these conferences the participants are addressed as 'children of Abraham' and their 'Israelite' customs, costumes and traditions are conveyed and displayed very explicitly.

Moreover, the proceedings are invariably opened by a Christian Lemba minister, (usually Chaplain Mhani), with Scripture reading (usually from the Old Testament) and prayer. The gowns and Jewish caps of the Lemba

$20 \mathrm{H}$. Von Sicard, Karangafolkets äldsta Missionshistoria, Stockholm: Snenska Kyrkans, 1943; Idem, Lemba initiation chants, Ethnos 2-4(1963); R. Finnegan, Oral literature in Africa, Dar-Es-Salaam: Oxford University Press. 1976.

21 H. Jason, Types of oral tales in Israel, Jerusalem: Israel Ethnographic Society, 1975; A.B. Lord, The singer of tales, Cambridge: Harvard University Press, 1960; also Vansina, Oral traditions as history, 40.

22 Apparently, the Lemba hold their conference as closely as possible to 10 October, which is Paul Kruger's birthday. This expresses their appreciation for the role Paul Kruger played as President of the ZAR (Zuid-Afrikaansche Republiek 1884-1902) in their history, when in public he declared the Lemba to be 'Jews'. In certain sources, the Lemba are known as 'Kruger's Jews' (cf Parfitt Joumey, 25). The LCA Conference also falls close to the Jewish New Year. I would not be surprised if in future, on account of influence from Jewish groups who wants to invest into the Lemba communities, this annual meeting will loose its 'original' connection (with Kruger) and be linked to the Jewish New Year. 
leaders and the T-shirts worn by many others often bear the Star of David with their totem, an elephant (Zhou), inside. ${ }^{23}$ Some respondents tell that the people in the Wedza district in Zimbabwe have an elephant with a star on its forehead as a totem, because a star guided them southwards in Africa. The Lemba explain that an elephant always remembers and therefore reminds them that they should remember their history and traditions. $^{24}$

It appears that during the LCA Conferences and other occasions, there is a conscious transferral and reinforcement of cultural and religious identity by means of their songs, symbols, prayers and recitations. Some of these songs, recitations and prayers will now be discussed.

Lemba Songes, Sayings, Recitations and Prayers

SONGS AND SAYINGS REFLECTING THEIR TRADING SKILLS

The oldest song I encountered was the following on the trading skills of the Lemba recorded in 1561/62 by the Portuguese Father Fernandes: ${ }^{25}$

Gombe zuco virato

Ambuze capana virato

The cow has leather for shoes,

and the goat has no leather for shoes.

This translation is debatable, especially when one reads the song recorded by Stayt: ${ }^{26}$

The best businessmen are the ones who bring the cattle home;

Those who bring home goats are nothing.

Unfortunately, Stayt did not provide the original text as well. This song does not only stress the fact that the Lemba were traders, but also how the world-view or interpretation by a translator can influence it in the outcome

23 Deist (A Concise Dictionary, 175) defines a totem as 'the creature or object venerated in totemism....' or totemism as 'the belief that some animal, plant or other natural object is a benefactor of one's tribe or clan and belongs to it or is ancestrally related to it.'

24 C. Bullock, The Mashona and the Matabele, London: Juta [1927] 1950:45, maintains that 'in this there may be a trace of Semitic inhibition combined with Bantu totemism" (cf Lv $11 ; 17$ and Dt 12;14).

25 H. Von Sicard, Lemba clans, Native Aaffairs Department Annual, 39 (1962), 68-80, quotations from 78 .

26 H.A. Stayt, Notes on the Balemba (An Arabic-Bantu tribe living among the BaVenda and other Bantu tribes in the Northern Transvaal and Southern Rhodesia), Journal of the Royal Anthropological Institute of Great Britain and Ireland 26 (1931), 231-238. Quote from p. 236. 
of an interpretation. However, a report by 'a Negro' Mahumane ${ }^{27}$ for the Dutch at Delagoa Bay in 1728 refers to the 'Walembers', this time in the vicinity of the Zoutpansberg, as being traders and a separate people. These two traits very often come to the fore in accounts on the Lemba and in the oral traditions of the Lemba themselves - even when other groups refer to the Lemba.

In 1908 Junod mentioned that most of the Lemba's merchandise would often consist of medicine and that they introduced fowl into the country. In 1938 Junod again noted that the Lemba were anxious to preserve their tribal and ritual purity and stressed that they were efficient 'traders' ${ }^{28} \mathrm{~A}$ man of importance is shown great respect when he is addressed as musa$v i^{29}$, nyakuwana ('the man who finds the things which are bought') or mulungu, probably 'White man' or 'the man from the North'. Jaques also contributed by adding family traditions which bear witness to the commercial activities of the old Lemba:

[A]n ancestor of Mosheh [a respondent], called Mbalanyika, was given the nickname of Gumboyi 'leg', because he used to travel much on business. When people mocked him because he did not plough and did not even possess a hoe, he used to say, Gumboyi baaza, mašango nda feza', My leg is my hoe, I walk about to every country ${ }^{30}$

This Lemba forerunner of the commercial traveller, evidently found it more profitable to devote all his time to trade, rather than to agriculture. In order to sell their wares such as medicine, metal work, pottery and textiles, they accepted grain, livestock or anything else they could use or resell, and they also undertook long journeys to find customers. ${ }^{31}$

An old Lemba praise song collected by Stayt also reflects their view of the past: Nemanga vhazungu vha no senna, vha no vha mbila ya sose ('Master of the monkey nuts, white men who come from Sena, who come from the place of the rock rabbits at Sose'). This praise song does not only

27 An African from the chiefdom of Mpfumo near the Dutch trading factory who had visited the Venda 'king' in $1727 / 28$ and who gave the Dutch important information they needed. This report was transcribed by the head of the Dutch trading station, J. van de Capelle (cf G. Liesegang, New light on Venda traditions: Mahumane's account of 1730, History in Africa 4, (1977) 163-181). They refer to Mahumane as 'a Negro'.

28 H.A. Junod, The Life of a South African Tribe, London; Macmillan, 1927:73; and Idem, Bantu Heritage, Johannesburg: Hortors, 1938:245-254.

29 buyer; cf Tonga šava = buy; a connection has also been suggested with Saba, Sheba; N. J. Van Warmelo (ed), A preliminary survey of the Bantu tribes of South Africa, Ethnological Publications 5, Pretoria: Government Printer, 1935:122.

30 A.A. Jaques, Notes on the Lemba tribe of the Northern Transvaal, Anthropos 26 (1931), 245-251, quote from p. 248.

31 Junod, Bantu Heritage, 248. 
emphasise that they were traders and that they looked different from others, but also indicates their location before they moved southwards. ${ }^{32}$ Schoffeleers refers to the Mwenye (Lemba clan) in Malawi ${ }^{33}$ who are very prosperous traders and keepers of cattle and in his personal notes De Vaal recorded a praise song usually sung for their chiefs:

Great trader,

Lion of the Induna.

He who pierces assailants,

Thundering on the white-ant hills,

Roamer of hills and vales.

Numerous are the only in the land,

Thunder of the land [my translation from Afrikaans].

This praise song once again emphasises that the Lemba are traders and that they know all the trade routes in the country (wherever that was at the stage when the song was sung; cf for various trade routes in De Vaal's personal notes). The information from these songs relates to the fact that there are still numerous Lemba who conduct their own businesses today. In fact, they feel strongly about these and believe that they should preferably not work for someone else. This indeed encourages intitiative to undertake their own businesses. Numerous Lemba who do have to work for others, prefer to work for Jewish people.

SONGS, PRAYERS AND SAYINGS REFLECTING THEIR DIETARY LAWS

One rendering of Lemba history records that Nkalahonye Mulembe ${ }^{34}$, son of a Karanga induna, among other young men from Mashonaland, went to look for work at Great Zimbabwe, 'when it was still under control of Jewish and Arab gold diggers' ${ }^{35}$ Nkalahonye was hired in the kitchen of an Arab and although he was accepted and liked, he still needed to be circumcised in order to cook for them. After he was circumcised (in private), he was much more acceptable to the Arabs. Later he married one of the Arab (Moslem or Jewish?) women, kept their customs and circumcised his own sons according to the 'Palestinian' law. ${ }^{36}$ It may be of some

32 Stayt, 'Notes on the Balemba', 237.

33 J.M. Schoffeleers, Mbona: The Guardian spirit of the Mang'anja, Unpublished D.Litt., 1988:26.

34 No indications are given when this leader lived and no specific date is connected to this narrative.

35 De Vaal, 'Die Lemba', 65; C.V. Bothma, 'Pedi origins', in: Ethnological and linguistic studies in honour of N. J. van Warmelo, 167-197, Ethnological publications, Vol. 52 (1969), Pretoria: Government Printer, p. 195.

36 De Vasal, 'Die Lemba', 65; M.M. Motenda, 'History of the western Venda and of the Lemba', in, N.J. Van Warmelo (ed), The copper miners of Musina and the early history of the Zoutpansberg, Ethnological Publications 8, Pretoria: Government 
significance that Nkalahonye kept the customs of the 'Arabs' and circumcised his sons according to the 'Palestinian' law. And again that he learned the new moon celebration and the circumcision from the Arabs and the Jews in Zimbabwe. It is of course true that some of the customs of the Arabs and that of the Jews are so closely related that it could have been very difficult to discern between the customs of the two groups.

One of the very strict laws of the Lemba, which is still kept by most of them, is that they may only eat the animals allowed to be eaten and only in the proper way. This old Lemba song ${ }^{37}$ summarises the list of animals that Nkalahonye (and other Lemba) was not allowed to eat:

The Jew does not eat a pig even the Mu-Lemba does not.

The Jew does not eat a hare even the Mu-Lemba does not.

The Jew does not eat a rock rabbit even the Mu-Lemba does not.

The Jew does not eat an owl even a Mu-Lemba does not.

The Jew does not eat an eagle even the Mu-Lemba does not.

The Jew does not eat an ostrich even the Mu-Lemba does not.

The Jew does not eat the crow even the Mu-Lemba does not.

Many other prohibitions, similar to those of the 'Arabians and the Jews of Jerusalem', held by Nkalahonye were recorded ${ }^{38} \mathrm{He}$ avers that probably when the work at the mines of King Solomon stopped, the Arabs and those who came from 'Palestine' went back. According to tradition Nkalahonye and his married sons Mbelengwa, Tanganalo, Sadiki, Mposi and Mpilo ${ }^{39}$ remained and traded mainly with arm, leg and earrings. ${ }^{40}$

Except for the elephant and above mentioned animals, the Lemba also have a taboo on the zebra, the rhinoceros and the hippopotamus. Other dietary laws which many scholars and others observed are that the Lemba bled slaughtered animals, only eat meat that is kosher killed by a Lemba ${ }^{41}$ and also do not eat pork. ${ }^{42}$ To the traditional Lemba, it is of great import-

Printer, 1940:51-70.

37 Once again oral traditions leave us with no chronology or dates. De Vaal, 'Die Lemba', 57; cf Marole, Kusakha, 3; note that the translation of the song by P.E. Maringa is presented verbatim.

38 Marole, Lusakha, 3.

39 Marole, Lusakha, 4 also adds Bakali.

40 De Vaal, 'Die Lemba', 57; Connoway, 'Herkoms'.

41 Junod, 'The Balemba of the Zoutspansberg', 278; Wangemann, Ein Reise-Jahr, 436; Theal, Records of south-eastern Africa, Vol 7:371; H. Von Sicard, Ngoma lungundu. Eine afrikanische Bundeslade, Studia Ethnographica Upsaliensia, 5 (1952), Uppsala: Almquist \& Wiksells Boktrycker, p. 161; S.D. Goitein, 'The Jews of Yemen', in A. J. Arberry (ed) Religion in the Middle East. Three religions in concord and conflict, Vol I. Cambridge: University Press, 1969:226-235, esp.231; Jaques, 'Notes on the Lemba Tribe', 246; Stayt, 'Notes on the Balemba', 235; Van Warmelo, 'Preliminary Survey', 122.

42 The Rev. Schlömann, Die Malepa in Transvaal, Zeitschrift für Ethnologie 26 (1894), 
ance that an animal should be slaughtered in the correct manner by a circumcised Lemba. The Lemba does not eat the blood of an animal, and a blessing or prayer (shidja) needs to be said over the meat. There are special sacred words for this blessing. Similar principles were found in this connection in early Israel, but these applied more specifically to the slaughter of animals at the altar. It may be that everyday customs were just not recorded.

Many scholars observed concurrences between the dietary laws of the Lemba and those found in the pages of the Old Testament (especially early Israel). Wessmann explains that the Lemba avoid all meat of animals which have cloven hoofs, and animals which do not chew the cud....They do not touch the meat of fallen animals....[they] kill the animals according to the Jewish rite, as if to render it "kosher". 43

Gayre of Gayre avers that the rejection of pork, or killing in the kosher manner by bleeding, would be a remarkable coincidence by itself, but when the prohibition of eating of hares, rabbits, scaleless fish and carrion is added to their list,

the probability against coincidence is so great that we have to accept the fact that the Lembas observe the Mosaic code, and that we have to explain its occurrence among this small tribe of traders who have Caucasoid genes and live in northem Transvaal and some adjacent parts of Rhodesia. Moreover, only the Lembas bleed animals to death as enjoined by the Mosaic code, and this act is restricted by them to the circumcised. ${ }^{44}$

The aforementioned old Lemba song does not only summarise the list of animals the Lemba were not allowed to eat, but also ensures reliability of transmission and reflects much of their religious beliefs and customs. Junod points out that it appears as if they keep these customs even without knowing why, and that they do this in order to preserve their identity as tribe. $^{45}$

MASTERS OF MAGIC ARTS AND MEDICINE MEN: PRAISES AND PRAISE SONGS The Sadiki clan are specifically known as the medicine men of war, 'a tribe that knew all the herbs/medicine of war' (Rudzi rwavo vaiva nganga

64-70, esp. 67; Theal Records of south-eastern Africa, VII:371; cf also R. Wessmann, The Bavenda of the Spelonken (Transvaal). A contribution towards the psychology and folk-lore of African peoples, London: The African world, 1908:129; Stayt, 'Notes on the Balemba', 235; Jaques, 'Notes on the Balemba Tribe', 246; Van Warmelo, 'Preliminary Survey', 122; Motenda, 'History', 65; Mphelo, 'The Balemba', 41; Von Sicard, 'Ngoma lungunda', 147; De Vaal, 'Die Lemba', 57. 43 Wessmann, The Bavenda, 129-132.

44 R. Gayre of Gayre, The Lembas or Vendas of Vendaland, Mankind Quarterly 8 (1967), 3-15, quote from 6-7.

45 Junod, 'The Balemba', 278. 
dzokurwa, vaiziva miti yose). The Hamisi clan again were known as 'medicine men who treated people in order to get children' (Basa ravo raivo rokusimikira). ${ }^{46}$

Parfitt notes that 'the descendants of the Moors had a huge reputation as men of magic and medicine and as such played an important role in African society... ${ }^{47}$ The Portuguese trader Antonio Caiado, who accompanied Don Gonçalo da Silveira to the court of Monomotapa in 1560, added to this supposition by his statement that 'Moorish ngangas ${ }^{48}$ were the principal wizards of the country' ${ }^{49}$ Parfitt connects the above facts to the explanation for the word Lemba that one finds in other sources: 'Conflicts of interest between the trade and social order may explain why Lemba - a word meaning 'to calm' (lembikisa) took the form of a therapeutic association, a "drum of affliction" (ngoma) ....' Parfitt considers it possible

that these Mwenye ngangas travelled further afield and established themselves elsewhere in Africa as a sort of secret guild. In any event, it is interesting that in West Africa a curious sort of cult, which took the form of a therapeutic association called a 'drum of affliction' [ngoma], was known as the 'Lemba'. Similarly in Angola, in Mbundu society (and perhaps in Zaire), the word Lemba refers to a noble and traditional elite. ${ }^{\text {so }}$

The ngangas are specialists, men skilled beyond their fellows and the number of different types is very large in the different clans. All this information correlates with the fact that to this day the Lemba are viewed as masters of magic arts and as medicine men.

SONGS, CHANTS, PRAYERS AND HORN-BLOWING DURING RITUALS OF PASSAGE

The rites of passage are ceremonies or rituals which accompany vital transitions during life, such as the transition from puberty to adulthood (circumcision), from outside to inside the tribe (e.g. rituals associated with marriage) or the Covenant of God, and from one cycle in nature to another (e.g. the new moon, new season or new year). ${ }^{51}$ Different songs, chants,

46 Von Sicard, 'Lemba Clans', 70; Idem, 'Ngoma lungunda', 70; D.C. Chigaga, 'A preliminary study of the Lemba in Rhodesia', History Seminar Paper, University of Rhodesia, 1972:10.

47 Parfitt, Journey to the Vanished City, 249-250; Stayt, 'Notes on the Balemba', 237.

48 Wizards or masters of magic arts. These skills are zvenly known among other peoples.

49 Theal, Records of south-eastern Africa, IV:102.

50 Parfitt, Joumey to the Vanished City, 250 and 269; of J.M. Jantzen, Lemba, 16501930: A drum of affliction in Africa and the new world, New York: Garland, 1983:3; J.C. Miller, Kings and Kinsmen, Oxford: Clarendon, 1976,69.

51 N. Smart, Worldviews. Crosscultural explorations of human beliefs, 2nd ed. New 
prayers and certain musical instruments play a vital role in the creation of the atmosphere and in the transmission of teaching content during these different ceremonies or festivals. Only a few of these will be briefly discussed below. Most of these are based on transcripts of interviews conducted during field study in the period 1994-1996.

Male circumcision (ngoma)

The Lemba practice of male circumcision is called ngoma. Ngoma in the African languages generally means drum (e g ngoma lungundu; see below) or dance, but not circumcision. It seems as though the associations among the central elements of the Lemba identity are so strong that this word is also used for circumcision.

William Ratsoma (alias Napi), a traditional healer in India Village, a Lemba community in Sekhukhuneland (Mpumalanga), was a most informative interviewee during the field research. Apart from being the traditional healer (from Mogabane), he is fully involved in the circumcision (ngoma) of males and initiation of females in Sekhukhuneland.

Napi was very cooperative in showing us the route up the Leolo Mountain, while also describing how the boys pass through the initiation ceremony. He described the atmosphere and the procedures, he sang every song or chant, usually sung by the elders of the tribe and recited at the important localities. Similar songs and recitations are also part of the teaching, when they, for example, conduct kurubha (circumcision teaching) in Zimbabwe at the Mberengwa Mountain. It has a secret meaning, which may not be revealed to the uncircumcised. In other words, the transmission of information during this ceremony takes place by means of songs, chants, recitations and so on. The information conveyed is usually not meant to be known by uncircumcised, since they are 'heathen' or 'unclean', and are not privileged to learn about it. What has become known over a period of time is that during the ceremony the 'novices' are informed about all facets of Lemba culture and history, especially about the secret ways and formulae to perform certain procedures and rituals.

Quoted below are two songs or chants used during the circumcision ceremonies in the Mberengwa District, in Zimbabwe (translated into Shona and into English). Special permission had to be obtained from Zivengwa Mposi, the brother of Chief Mposi in Mberengwa to publish these. These songs are presented with English translation where possible:

Oh! he he he he-e

Oh! hiye hiye hiye

Oh! hera Maria ho here here re

Here hiye-e
Oh! (He he he he-e) Humming

Oh! (Hoye hiye hiye) Humming

Oh! Holy Maria (ho here he - he) Humming

(Here hiye-e) Humming

Jersey: Prentice Hall, 1995:129-133. 
Oh! hera Maria ho here he-he

Oye hive hiye

Oh nhamo inouya here he he he

Ewoye hiye ye a! Heya heya hee-hee vaMaria wonde

Oh hiye he dzvotsvo
Oh! Holy Maria (ho here he he)

(Oye hiye hiye)

Oh! poverty will come (here he he he)

Ewoye hiye ye a! Heya ..

Holy Maria definitely come

(Oh hiye he) upheaval

On face level this song does not seem to have a special meaning, but this song or chant tells much about the Varemba tribe (as Mposi calls them). According to Mposi, it reflects their traditional religion, especially as it was practised by their ancestors, but the song is so secret that no other person or tribe knows it. Others are not aware of its real meaning. Quite significant, though, is the fact that the Christian notion of 'Holy Mary' is incorporated into this secretive circumcision song. On the one hand the warning is uttered that poverty will come because of something not clear to outsiders. On the other hand the song ends with the affirmation that Holy Mary will also come. Whether her coming should be seen as a warning or rather as an act of salvation to those being captured in the circumstances in which the song is sung, is not known. Why 'Holy Mary' is specifically used in this song is also not clear, since the Mberengwa area in which this song is collected is not Roman Catholic, but mainly Lutheran and (Dutch) Reformed. It is possible that her name is not used in a religious sense, but rather for their secret purposes.

\section{SAISA WAKAFA}

Saisa wakafa akafira mubani raRengwe

Hiye hiye yiye here

Ho! Here hiye woye

Hiye hiye saisa iwe

Ho! Here ha! Hoye

Hoye Saisa wakafa ha e he e eha eha

Hongo kubani revengwe

Ha! e - ere here ha! Heya heya - heya

Huwe yi Saisa iwe

Ho! yere iye iye

Hiye yi saisa here

Hoiyere ha woye - e

Ho! Kubani rokwedu

Ha-a! Eha-eha e-eha e-eha chakafirapo

Hongodzi yaisa mposi

Ha! Eha here ha heya heya chakafira Maroza

Mposi explains that this second song reflects some of the problems they came across when they were in the jungle (during circumcision). It is about 
Saisa who died on the plain of Rengwe (Mount Mberengwa), because the enemy had bewitched him. He died at Maroza probably because his parents did not confess all their sins before their son went for circumcision (as Mposi explained to me). Both songs form part of their teaching or kurubha during circumcision.

Other secret or special words used by the priest when performing the circumcision is El pharusia, which they interpret as God, the wise one. The respondent does not know 'whether it is a prayer or ... an address, actually that wisdom to God, or whether it is the wisdom from God to the priest to circumcise.' The Hebrew phrase that most closely relates to this, I think, could be el pharusia. Pharas means 'to make distinct', or 'to declare' or 'to separate' ('god of separation'). The Greek word $\pi \alpha \rho$ ov (second coming) could perhaps also be applicable in this context ('god of the second coming'). A possible Arabic meaning for this word should also be investigated. Mposi contends that '(S)elemane shidja' are other Hebrew words of which he does not know the meaning anymore, but which are used during circumcision or animal slaughter. Selemane could be a corrupted form of the word Solomon. ${ }^{52}$

\section{The First Fruit Festival}

A festival that seems to reach back to an Old Testament festival (cf Lv 23:10; Dt 16:11; Is 9:2) is the Feast of the First Fruits. ${ }^{53}$ The older people in the community can still recall how they took part in such an occasion once a year. Although 'the majority of the Lemba is converted to Christianity, in their practical adherence to time they stick to their First Fruit Festival. They stick to the time around December and others when they collect all the seeds'. The ingathering of the seed usually takes place during springtime. On these occasions the horns are blown and thereby God is requested to make their seeds fruitful and let them multiply (Mathivha 1999). A message is called out on this musical instrument. ${ }^{54}$

Already in the early fifties of the previous century, Nabarro (who accepted the Jewish faith), and her Jewish husband came across a group of

52 A. Ahuja, Are the Lemba a lost tribe of Israel? Star (10th March 1999), Johannesburg.

53 This is a custom which also occurred among all Black tribes. Especially the Swazi's Incwala and umemo feasts, are similar and undoubtedly unique to themselves (Private communication from Prof. F.C. De Beer, UNISA, 1997).

54 Private communication from M. Mathivha, Shayandima, 1999. Ratsoma from Apel in Sekhukhuneland remembers that the First Fruit Festival took place after the first fruit (he remembers the sorghum) was harvested. He then actually demonstrated how they knelt down to drink from a pot, while the women poured a special brew of the sorghum into the pots. It is noteworthy that his mother took the lead in this ceremony during which she usually prayed to their forefathers for a blessing on the food. $\mathrm{He}$ remembers that the children would drink and eat first at such occasions. 
people (long before they knew about the Lemba or the Mwenye) in Southern central Mozambique, then still a Portuguese colony. They mentioned that there was somebody with a kudu-hom, and the man was playing little phrases, neumes or whatever they were. It struck them as being extraordinarily like the Jewish New Year service (shofar ceremony in September). The man did not just play, but somebody called the name of the phrase and then he sounded the phrase. The Nabarro's recorded these calls and played them to other Jewish scholars. They compared them to those in a Jewish prayer book reflecting the playing on a Jewish New Year's day in the synagogue, to determine how they corresponded to the recordings made in central Mozambique. It appeared later that the group was most probably the Mwenye, who are closely related to the Lemba in South Africa. It was only later found that the Lemba (in South Africa) employ similar calls on the horn when they call the ingathering of the seeds. ${ }^{55}$

\section{The New Moon ceremony}

During a special Lemba Cultural Association Conference in April 1995, Mhani (Chaplain of the LCA) demonstrated and explained the activities surrounding the New Moon Festival in the Lemba communities. At about the time of the new moon, a bowl is placed under a tree or in the shade of a hut. Then, a day before the moon is seen by anyone, sometimes two days before the moon becomes visible, it reflects in the water in the bowl, usually around noon. The one who sees the moon before the others shouts: 'Ha lea e bonala lapeng' ([the moon] is not visible at the lapa) and runs to the chief to inform him. Then the chief sends his servants to the river to see if they can really see the moon in the dish. If they confirm it, the chief will blow the hom and the indunas ${ }^{56}$ will follow suit, blowing their homs (1969:4). When the people hear the horns, they will leave everything behind and run to the river, since they got the message transferred by the blowing of the horn. All the old men and old women shave their heads and everybody fasts for the rest of the day. The following day no work is done. It is kept as a day of cessation and everybody brings food to the chief. That evening the Lemba would look at the moon and say, 'This is the batsetse's moon, our moon has been seen in the pot.' If a person's head is not clean-shaven he or she becomes foolish. The Lemba women specifically shave off their hair to become wiser. ${ }^{57}$ This ritual is also accom-

55 Private communication from F.R.N. Nabarro, 1999. Nabarro is a Professor of the University of the Witwatersrand and husband to the late Dr Margaret Nabarro in Auckland Park, Johannesburg. Mathivha explained me in 1999 that horn blowing is used for calling together meetings (usually in September), when they ask God to bless and multiply their seeds (as mentioned above).

56 A Zulu word used by Marole, Lusakha, 4.

57 Dos Santos (R.E. Gregson, Trade and politics in South-East Africa: The Moors, the 
panied by different chants and songs.

SAYINGS AND RECITATIONS ON THE NGOMA LUNGUNDU ('THE DRUM THAT THUNDERS')

Another instrument which plays a major role in the traditions of the Lemba people is the so-called ngoma lungundu or the drum that thunders. There is a Lemba saying: 'Once we had a drum because we were a holy people and once we had a book because we are a chosen people.' The narrative behind this story of ngoma lungundu (the name refers to a particular sound of the drum) and the emotion of the specific experience of God, behind this, classifies this as experiential.

The ngoma lungundu (some say it was made of ivory[wood]) was at one stage located somewhere north of the Limpopo in a mountain, where the Lemba and the Senzi (Venda) lived together and experienced the sound of the sacred drum with awe and fear, since it was perceived as the voice of the great god, Mambo wa Denga, 'king of heaven', speaking to them. For many days they felt afraid as they had been aware of the far away rumbling of the earth. The high priest, who was the mouthpiece of the king would hear the prayers of the councillors and transmit them to the king when the drum 'spoke' again, and the people trembled and fell on their faces in terror, making humble obeisance, saying: 'Great king! Male elephant! Light of the country! Great ancestral spirit! Ruler of heaven!' Clouds of smoke were coming from the mountain, blackening the sky in a terrifying manner. Blazes of fire were seen above the central cloud. In complete silence the king spoke with a voice that sounded like rolling thunder. The high priest interpreted the words of the king. He was deeply dissatisfied with the evil practices of his people and ordered them to stop, otherwise he will afflict them and vanish and go and live beneath the earth from where he will slay them by earthquakes and many other terrible things that would befall them. Many of them fainted at the sound of the voice, and the fear of the others grew with the increased shaking of the earth and the blazing of fire against the black smoke. Although many of the other peoples died, nothing happened to the Lemba, as they lived devoted to Mutumbuka-Vhathu, their father. ${ }^{58}$

Portuguese and the Kingdom of Mwenemutapa, African Social Research, 16, 413-446 esp. 419) refers to the similarities between the practices of the 'Moors' in South-East Africa and those of the Lemba. He wrote: 'The Kaffirs hold a great feast on the day of the new moon and I think they got this custom from the Moors who are scattered about this land and do the same...' And again 'the principal observance, in which they are almost exact, is celebrating, with great feasting, every new moon, upon which occasion they usually get intoxicated - although their creed forbids them to take wine.'

58 D. Möller-Malan, The chair of the Ramapulanas. Cape Town: Central News Agency, $1953,1-7$. 
For a long time the ngoma-lungundu was heard no more and then one day the high priest (from their family of priests), Dzomo-la-Dzimu, received instructions to beat the drum in a special way. Later MutumbukaVhathu gave his son (Tshilume) a small drum which he called by the same name of ngoma-lungundu, 'which possessed all the magic and killing powers of the old drum, also the spears and banner of royalty and many badges, white cotton garments and the madi and denga ${ }^{59}$ royal beads'. These beads were worn by the high priest as a distinction of his rank and he puts those beads around his neck especially during the circumcision ceremonies. The tradition holds that Mutumbuka-Vhathu also said:

Call the Lemba to carry these things, and take charge of them on the journey to the south .... Do not fear, for everything will go well. For have you not in your midst the magic drum? Beat the rain-making drum and all that is alive will be seized with fear and fall down as if in death, all excepting yourselves. ${ }^{60}$

The ngoma lungundu was considered holy and was not to be touched improperly or placed on the bare ground. Inside the drum were sacred objects which belonged to the Vhasendji (properly the Venda). Therefore, because of their magical skills especially during warfare, the Lemba had to carry the drum (for the Vhasendji) and it was guarded at night by a mythical pillar of flame. If this magic drum was lost, calamity would befall them. ${ }^{61}$

Idrisi records [circa 1150]) that the Senzi (Zanji ${ }^{62}$ people) - possessors of the ngoma lungundu, were in fact forced from their territory and down into the Sena area (at the Zambezi). These people of the magic drum, calling themselves the BaSenzi (probably the Venda), at that stage became closely associated with the Lemba in the same area. ${ }^{63}$

Some believe that the original drum (ngoma lungundu) which helped them on their joumey from Sena might still be in one of the caves on Dumghe Mountain in Zimbabwe or perhaps somewhere in the Soutpans-

59 Madi means 'blueish water' and denga means 'heaven'. Together they are 'blueish beads which came from heaven'.

60 Möller-Malan, The Chair of the Ramapulanas, 1-7.

61 G. Bloomhill, The sacred drum, Cape Town: Howard Timmins, 1960, 165.

62 J.E. Mullan, The Arab Builders of Zimbabwe, Umtali: Rhodesia Mission, 1969:7396. Alternative term for Senzi, Zindji, Vhazhenzhi, Zang, Zing or Zenj (cf Theal Records of south-eastern Africa, VII:200; Junod, Bantu Heritage, 25; J.B. De Vaal, Die Vhalemba, die Semitiese Bantoes, Suid-Afrika (Feb. 1947), 15-48; Gayre of Gayre, 'The Lembas', 33-41,165, 200; Connoway, 'Herkoms', 13-14.

63 Cf Junod the Life of a Southafrican Tribe, 430; Van Warmelo 'Preliminary Survey', 122; De Vaal 'Die Vhalemba', 46; Von Sicard, Ngoma lugunda; Gayre of Gayre The Lembas, 5; P. Davison, Lobedu material culture, Annals of the South African Museum 94 (1984,3), 42-201, esp. 119. 
berg area. ${ }^{64}$ But they are very secretive about its whereabouts. The fact that the - for some fearsome - drum may still be in the mountains, but guarded very well, does not only keep the traditions alive, but also contributes to the experiences of the mysteriousness of the supernatural powers or influences, linked to the drum. In fact, the Lemba see the drum as a symbol of their deity's presence.

Although the Lemba themselves do not mention a parallel between their drum and the Ark of the Covenant, many scholars and observers do refer to such parallels. In his book Ngoma Lungundu (The drum of the ancestors), Von Sicard examines the parallels between the ngoma lungundu story and the Old Testament story about the Israelite Ark of the Covenant (cf Ex; $1 \mathrm{Sm} \mathrm{3}$; 4), and those between ngoma lungundu and the Ethiopian Kebra Nagast - 'Splendour of Kings' in order to prove his theory as to how the Old Testament traditions entered the former Rhodesia. ${ }^{65}$

From different songs and narratives it could possibly be inferred that the narratives of the ngoma lungundu already existed very early in the thought-world of the Lemba and of Venda (Senzi). However, the link of that to the Ark of the Covenant was possibly only suggested later by Jewish groups or missionaries. Nevertheless, such experiences of the divine (as described above), associated with fire or other violent manifestations are quite pervasive in their traditions. ${ }^{66}$ These examples reflect and facilitate obtaining a clearer picture of certain threads in the world-view of the Lemba: in the relationship between divine and human each partner has certain rights as well as responsibilities.

\section{Conclusion}

Much of the Lemba's supposed heritage and religio-cultural practices are preserved and reflected in their oral traditions, especially through their songs, recitations and prayers. We have to conclude that influence from the Jewish or Israelite religion found the strongest expression in the Lemba culture, probably through their historical connection with Jewry or Israel-

64 Von Sicard, Karangafolkets, 140; Parfitt, Joumey to the Vanished City, 142.

65 Von Sicard's book Ngoma lugunda was partly based on the notes of the missionary Rev J. Othenius (1938). For the parallels of the drum and the Ethiopian relation: ibid. 10-36 and 170-175. The 13th century Kebra Nagast relates how Prince Menelik, son of King Solomon and Queen Makeda of Sheba, visited Jerusalem and returned to the South with an escort of Israelite priests, who stole the sacred Ark out of the Temple at Jerusalem, left a replica in its place and took the real ark to Axum (Ethiopia). In the same manner, the Lemba, in the ngoma lungundu story, carried (for the Vhazendji) with them the sacred drum down towards Southern Africa (cf Hendrickx, 'The ancient origin', 182).

66 S. Niditch, Ancient Israelite Religion, Oxford; University Press, 1997:47,48. 
ites, and even through Christianity. Junod's concern that the advent of European civilisation was rather disastrous to the Balemba, because European wares and wire were surplanting theirs, and Christianity caused them to lose their special characteristics, seems to have been to a certain extent unwarranted. ${ }^{67}$ The arrival of Christianity most probably rather reinforced the ancient traditions and practices of the Lemba. The 'success' that the Christians had in the conversion of most of the Lemba could be seen as a result of their close relationship with the traditions, practices and lifestyle preached in the Bible. Whether the Lemba had merely assimilated the similarities between themselves and Jews or Christians in their reflections on their own religious heritage, is impossible to say. It seems, however, that their self-identification (mainly through their songs, recitations and prayers) both evidences and conceals a much older and very complicated religious identity.

The above-mentioned songs, recitations and prayers are not specifically church or Christian songs or prayers, but are rather their ancient, cultural or ceremonial songs. Only in the mentioning of the name of 'Holy Mary' does one find a slight indication of a possible influence on these traditions from Christianity. If this is a proper addition to their song or tradition, it seems as though the Lemba simply added something which is valuable to them to the content of their existing song or tradition and transferred it in this new way to the next generation. It seems, however, that sung messages do ensure reliability of transmission. Very few 'new' elements seem to have been added over the years. In the case of the Lemba, not only does the transmission of religious beliefs take place through their songs, chants and recitations, but important historical events, cultural background, and traditions of origin are similarly transferred. At one stage or another it may have occurred that older information was replaced by newer, 'more important' information or content. This could have been the case with the transmission of traditions in the case of early Israel as well, and could therefore have important implications for the study of oral traditions among the early oral cultures.

There may be a possibility that the Lemba culture does have an influence on the songs of the Christian churches to which most of them belong, but this needs to be investigated.

A study of the function or social meaning of praises and praise songs within the Lemba culture (and elsewhere in Africa) can probably assist us in understanding psalms such as 'royal psalms' (Pss $2 \& 110$ ) and hymnic theophanies. ${ }^{68}$

A whole new world could be opened to the Old Testament scholar if an

67 Junod, 'The Balemba', 286.

68 Cf C.F. Swanepoel, Orality and literariness: the interface of values, Joumal of Northwest Semitic Languages 20 (1994), 143-154, esp. 150-154. 
intensive study could be made of, for instance, the correlation between the (probably) Mwenye or Lemba horn-blowers in the 1950s, recorded by Nabarro in central Mozambique, and that of the horn-blowing during the shofar in the Jewish communities.

One has to conclude, though, that it appears that through their songs, recitations and prayers there is a conscious transferral and reinforcement of cultural identity and that mainly reflect their understanding of their origin and the belief that their religio-cultural practices (embedded in an African culture) were transmitted by their Hebrew ancestors. ${ }^{69}$

* Dr. Magdel Le Roux is a lecturer in Old Testament at UNISA, the University of South Africa in Pretoria. The material in this article was mainly taken from her unpublished Ph.D. dissertation 2000): 'In search of the understanding of the Old Testament in Africa: The case of the Lemba'. Another recent publication is "Lost Tribes of Israel in Africa?", Religion and Theology 6 (1999), 111-139. Her address: Dept. of Old Testament and Biblical Archeology, PO Box 392; UNISA, Pretoria 0003, Republic of South Africa; e-mail: lrouxm1@unisa.ac.za

69 The financial assistance of the 'Stichting Studiefonds voor Zuidafrikaanse Studenten' (February to April 2000) in Amsterdam, Nederland, is hereby acknowledged. Opinions expressed and conclusions arrived at are those of the author and do not necessarily concur with those of the Stichting. 